\title{
ANALISIS KUALITATIF MANFAAT PEMAHAMAN WARGA JEMAATTENTANG SEJARAH GEREJA LOKAL DI HKBP RESSORT TAMPAHAN
}

\author{
Bernhardt Siburian \\ Institut Agama Kristen Negeri (IAKN) Tarutung \\ Korespondensi: siburian.bernhardt@gmail.com \\ Meditatio Situmorang \\ Institut Agama Kristen Negeri (IAKN) Tarutung \\ meditatiositumorang@gmail.com
}

\begin{abstract}
This study aims to determine the benefit index of adult congregation members' understanding in the history of the local church in the development of faith in HKBP Tampahan District XI Toba Hasundutan located in Tampahan Village, Toba Regency, North Sumatra Province 2019. Primary data were obtained from answers interview questions to 15 respondents who know and understand the history of the local church. This study was a descriptive qualitative approach with structured interview methods about the implementation of church holistic stewardship in the period 1901-1937. The results of secondary data showed that the index of the benefits of their understanding of history was $72.54 \%$. Based on the results, recommendations are given that church ministers and historical figures must continue to make intensive refreshment for the young generation of the church because it has been proven to have supported the life of the church and the family of the congregation. Keywords: analysis, the benefits of understanding, the history of the local church, HKBP Tampahan.
\end{abstract}

Keywords:

analysis, the benefits of understanding, the history of the local church, hkbp tampahan

\begin{abstract}
Abstrak
Penelitian ini bertujuan untuk mengetahui indeks manfaat pemahaman anggota jemaat kaum dewasa tentang sejarah gereja lokal dalam perkembangan kepercayaan di HKBP Ressort Tampahan Distrik XI Toba Hasundutan yang berada di Kelurahan Tampahan, Kabupaten Toba, Propinsi Sumatera Utara Toba Tahun 2019. Data primer diperoleh dari jawaban pertanyaan wawancara terhadap 15 orang responden yang mengetahui dan mengerti tentang sejarah gereja lokal. Penelitian ini menggunakan pendekatan kualitatif deskriptif dengan metode wawancara terstruktur tentang pelaksanaan penatalayanan holistik gereja periode tahun 1901-1937. Hasil analisa data sekunder jawaban responden menunjukkan bahwa indeks manfaat pemahaman mereka tentang sejarah gereja lokal di HKBP berada pada angka 72,54 \%. Berdasarkan hasil ini diberikan rekomendasi bahwa pelayan gereja dan tokoh sejarah harus tetap melakukan penyegaran intensif bagi generasi muda gereja sebab telah terbukti telah menopang kehidupan gereja dan keluarga jemaat.
\end{abstract}

Kata Kunci:

analisis, manfaat pemahaman, sejarah gereja lokal, hkbp tampahan 


\section{Pendahuluan}

Gereja dalam tugas pelayanannya, menekankan tidak hanya pada satu tugas panggilan. Gereja semata-mata menjalankan tugas bukan hanya pada bidang Koinonia (persekutuan) saja, atau hanya menjalankan tugas Marturia (Kesaksian). Di beberapa gereja tugas Pelayanan (Diakonia) begitu diperhatikan tetapi dua hal di atas kurang menjadi perhatian. Tiga tugas tersebut harus dijalankan bersama dan saling mendukung satu sama lain seperti sebuah pilar yang menyokong bangunan untuk dapat berdiri dengan tegak.

Secara empiris, tugas dan pekerjaan Pelayanan (Diakonia) juga tertulis di dalam Perjanjian Baru (Kis. 6:2; 1Kor. 9:13; 1 Pet. 1:12, dyb), bahwa sisi tugas Pelayanan (Diakonia) dipandang sebagai salah satu wujud penampakan buah pemberitaan Injil yang manfaatnya dapat dirasakan secara langsung atau tidak langsung oleh umat percaya. Manfaat Pelayanan (Diakona) gereja yang dirasakan oleh umat percaya tentu saja merupakan bentuk pelayanan kasih nonverbal, tetapi merupakan tindakan empiris yang dapat mengarahkan kepada pengalaman transformatif ${ }^{1}$ umat percaya dalam beberapa bidang, misalnya ekonomi. Pokok inilah yang ingin diungkapkan oleh tim peneliti dalam tulisan ini.

Sejarah gereja telah mencatat bahwa Injil Yesus Kristus telah sampai ke bumi Indonesia di tengah situasi kemajemukan, para misionar telah datang sejak abad ke 17, dan sekitar tahun 1860-an telah datang ke pulau Sumatera, secara khusus di Tanah Batak oleh badan zending Rheinische Missions-Gesellschaft (RMG). Para misionar bekerja dengan sangat tekun menyebarkan Injil, mula-mula di daerah Sipirok. Tidak lama sesudah itu sangat cepat sampai ke arah Tapanuli Utara termasuk ke daerah Toba Samosir, atau tepatnya di daerah Tampahan. Mereka mulai mengadakan pelayanan dan mendirikan gereja di sana pada tahun 1888.

Strategi pengembangan gereja yang dilakukan pada masa misionaris secara umum adalah berbasis pada pelayanan holistik (menyeluruh) atau 'misi holistik'. ${ }^{2}$ Misi yang berfokus pada Injil kasih karunia. Isinya mengenai kekudusan dan anugerah Allah, manusia berdosa dan keharusan untuk bertobat, Kristus dan karya penebusan-Nya. Itu sebabnya setiap kali seseorang merenungkan kembali kasih Allah melalui pengorbanan anak-Nya yang tunggal, Yesus Kristus di kayu salib dan bertobat dengan sungguh-sungguh. ${ }^{3}$ Selain memberikan pelayanan kerohanian (spiritualitas, kepercayaan, iman), pelayanan akan kebutuhan jasmani, secara khusus tentang pemberdayaan ekonomi anggota jemaat melalui pertanian dengan membimbing warga menemukan, menanam bibit yang berkualitas, seperti padi, mangga, pisang, alpukat, kopi, dan lainnya. Dalam bidang pendidikan dengan mendirikan sekolah formal seperti Sekolah Rakyat (SR), SD sekarang. Bidang kesehatan, pelayanan mereka menghasilkan buah yang baik, dan ternyata warga jemaat pada masa lalu menikmati buah pelayanan holistik tersebut.

Misionaris pertama yang bekerja di daerah Tampahan adalah Tuan Kaiser. Dengan berbagai upaya beliau berusaha mendirikan bangunan gereja pada awalnya yang sangat

\footnotetext{
${ }^{1}$ Krido Siswanto, "Tinjauan Teoritis Dan Teologis Terhadap Diakonia Transformatif Gereja," Jurnal Simpson (n.d.): 95-120.

${ }^{2}$ Misi gereja yang holistik mencakup pelayanan pemberitaan Injil dan pelayanan (Diakonia); bahwa diakonia merupakan komponen inti dari Injil itu sendiri, tentang arti menjadi gereja, sebagai bagian hakiki pemuridan yang mengarah kepada perubahan dan transormasi social yang saling berhubungan dengan Kerygma (pemberitaan, Marturia) dan Koinonia (berbagi jamuan di atas meja), Thomson M. P. Sinaga and Bonar H. Nababan, eds., Bermisi Di Dalam Konteks, Transformasi Rekonsiliasi Pemberdayaan, Suatu Sumbangan Lutheran World Federation (LWF) Untuk Memahami Dan Melaksanakan Misi (Tarutung: Kantor Pusat Huria Kristen Batak Protestan [HKBP], 2008)., 48-49.

${ }^{3}$ Yosua Camerling and Hengki Wijaya, "Misi Dan Kebangkitan Rohani: Implikasi Misi Allah Bagi Gereja," Jurnal Ilmiah Religiosity Entity Humanity (JIREH) 1, no. 1 (2019): 57-71.
} 
sederhana. Dia juga melakukan berbagai hal untuk memajukan warga dalam bidang ekonomi serta memberdayakan seluruh lahan dan pekarangan gereja, yang sebelumnya pekarangan tidak menghasilkan apa-apa. ${ }^{4}$ Akan tetapi dalam dinamika perkembangan sejarah tersebut lambat-laun semakin menurun. ${ }^{5}$ Akibatnya sebagian aset gereja diserahkan kepada pemerintah. Salah satu penyebabnya mungkin saja gereja tidak sanggup mengelola sekolah tersebut dengan baik.

Melalui percakapan informal yang dilakukan tim peneliti terhadap para majelis HKBP setempat, tim peneliti juga mendengar bahwa ada kesan bahwa generasi jemaat kelompok usia dewasa saat ini sudah melupakan sejarah gereja lokal mereka sendiri yang dirintis oleh para misionaris terdahulu. Hal ini juga diduga menjadi salah-satu penyebab dinamika perkembangan sejarah tersebut lambat-laun semakin menurun. Kemudian tim peneliti juga mendengar akan adanya kerinduan dan keinginan yang tumbuh di tengahtengah jemaat agar pelayanan yang holistik itu dibangkitkan kembali, misalnya dengan mengolah kembali lahan yang masih tersedia lebih kurang dua hektar. Dengan menanam bibit unggul dari jenis buah-buahan, padi dan lain sebagainya. Agar gereja dan pekarangannya boleh menjadi tempat percontohan atau pilot proyek bagi seluruh warga HKBP.

Kemudian tim peneliti juga mendengar adanya kecenderungan bahwa pelayanan gereja masa kini lebih hanya menitikberatkan hal-hal kerohanian semata, dan mengabaikan hal-hal jasmani sebagaimana pelayanan holistik pada masa pelayanan para misionaris. Dengan demikian menjadi penting bagi tim peneliti untuk mengetahui dan menganalisis bagaimana warga jemaat HKBP Tampahan memahami sejarah gereja mereka sendiri dalam perkembangan kepercayaan mereka.

Salah satu tujuan penting memahami sejarah gereja lokal bagi warga jemaat adalah untuk menelusuri asal-usul nenek moyang rohani, yaitu tentang orang-orang yang memperkenalkan Yesus Kristus bagi setiap individu dan keluarganya. Selanjutnya secara umum, pemahaman tentang sejarah mempunyai manfaat diantaranya: ${ }^{6}$ a) Sebagai pengetahuan tentang masa lampau, yang berguna untuk pemecahan permasalahan dalam kehidupan di bidang ekonomi, politik, sosial dan budaya. b) Sebagai pedoman atau gambaran, untuk membentuk identitas setiap masyarakat menjadi lebih baik, sempurna serta hidup lebih layak. c) Untuk menumbuhkan suasana menyenangkan sebab sejarah mengandung karya seni budaya. d) Sebagai pemberi inspirasi atau semangat untuk bangkit dari keterpurukan di masa lampau hingga mencapai keberhasilan untuk masa kini.Menurut peneliti, manfaat sedemikian juga berlaku bagi sejarah gereja. Jika dihubungkan dengan manfaat sejarah di atas terhadap pemahaman anggota jemaat terhadap sejarah gereja mereka sendiri, seharusnya warga sudah mengalami banyak kemajuan dalam menikmati kehidupan ini.

Seorang sejarawan gereja HKBP, J. R. Hutauruk mengatakan: ${ }^{7}$ pertama,melalui pembahasan dan pemahaman sejarah gereja akan dipahami masa lampau, dan masa lampau akan menciptakan keadaan sekarang, lalu keadaan sekarang yang menentukan situasi masa depan. Jadi memahami sejarah gereja sangatlah penting, bukan demi masa lalu, tetapi

${ }^{4}$ Mangapul Marpaung and dkk., eds., Barita (Sejarah) Huria HKBP Tampahan Resort Tampahan Distrik XI Toba Hasundutan Taon 1888-2013 (Balige, 2013)., 9-17 dan juga wawancara dengan Pendeta HKBP Resort Tampahan, Pdt. Sarlen Lumbantobing, S.Th., M.A., tanggal 28 Maret 2019.

${ }^{5}$ Tim Peneliti, "Wawancara Terhadap Pendeta HKBP Resort Tampahan (Pdt. Sarlen Lumbantobing, STh, MA.)" (Balige, 2019).

${ }^{6}$ Rick Cornish, 5 Menit Sejarah Gereja $\square$ : Kebenaran Maksimun Dalam Waktu Minimum (Bandung: Pionir Jaya, 2005)., 17.

${ }^{7}$ Gomar Gultom, ed., Bunga Rampai Penghargaan Atas Pengabdian Pdt. Dr. J. R. Hutauruk, Menggapai Gereja Inklusif (Kantor Pusat HKBP Pearaja, 2004).,421-422. 
orientasi untuk masa depan.Kedua, dengan menghargai para tokoh gereja sangat bermanfaat untuk menjadikan generasi muda atau generasi selanjutnya menghargai hal-hal yang telah dicapai dan dimiliki oleh gereja, masyarakat dan negara pada saat ini juga, untuk berjuang mewariskan yang lebih baik lagi ke generasi yang akan datang. Orang yang lupa akan sejarah termasuk menjadi orang yang terhukum untuk mengulanginya. Artinya, apabila sebuah masyarakat memahami betul sejarah kehidupannya, kemungkinan besar kesalahan masa lalu tidak akan terulang. Demikian halnya dengan pemahaman tentang sejarah gereja lokal, sebagaimana warga jemaatnya yang sudah menikmati hasil pelayanan para pendahulunya di masa lalu tentu akan berjuang mempertahankan pekerjaan yang baik tersebut. Sebagai warga jemaat yang belajar, hasil jerih usaha nenek moyang yang sudah berhasil pada masa lalu dapat dipakai sebagai pijakan untuk menciptakan yang lebih baik lagi di masa depan.

Bertitik-tolak dari latar belakang masalah di atas tim peneliti merasakan bahwa pokok manfaat pemahaman warga jemaat tentang sejarah gereja lokal sangat urgen dibahas pada masa kini. Tidak jarang anggota jemaat kaum muda dan dewasa mudah terjebak dalam konflik internal gereja. Mereka sangat fokus pada pergumulan yang muncul di setiap generasi baik itu mengenai program kerja maupun anggaran kegiatan dan belanja operasional gereja tanpa sebab yang jelas ataupun objektif. Setiap generasi baru muncul, persoalan demi persoalan yang hampir mirip kerap muncul berulang-ulang. Mereka lupa bahwa para nenek moyang gereja mereka terdahulu sangat mengedepankan persatuan dan kesatuan hati dalam membangun dan mendirikan jemaat itu pada mulanya. Mereka juga telah banyak memberikan pengorbanan moral dan materil yang tidak sedikit sehingga generasi gereja saat ini masih tetap ada dan berdiri. Mereka juga telah berjuang demi masa depan komunitas jemaat, masayarakat dan keluarga anggota jemaat itu sendiri.

Mempelajari sejarah termasuk menerjemahkan informasi dari catatan yang dibuat oleh orang per orang, keluarga dan komunitas. Hikmah mempelajari sejarah sangat besar bagi kehidupan yang akan datang. Salah satu kutipan yang paling terkenal mengenai sejarah dan pentingnya belajar sejarah ditulis oleh filsuf Spanyol bernama George Santayana adalah: "Mereka yang tidak mengenal masa lalunya, dikutuk untuk mengulanginya." Ungkapan ini menjadi rambu akan pentingnya mengingat peristiwa yang sudah lampau bagaimanapun situasi dan kondisinya, baik manis ataupun pahit. ${ }^{8}$ Melalui pemahaman sejarah akan mendapatkan pelajaran penting tentang keberhasilan dan kegagalan para pemimpin dalam kepemimpinannya di tengah-tengah masyarakat.

Kebiasaan berpikir dan bertindak historis (berdasarkan sejarah) dalam Pelayanan (Diakonia) gereja dapat menyadarkan para pelayan bahwa hal-hal yang ada dan yang dimiliki saat ini adalah sebuah muara dari proses-proses yang sangat panjang di masa lalu. Kesadaran akan fakta sejarah dapat merangsang para pelayan untuk menganalisa setiap proses yang terjadi sehingga dapat memunculkan keterbukaan untuk perkembangan atau perubahan selanjutnya bahkan di masa depan. Hal inilah yang menjadi titik berangkat pertama bagi warga jemaat (secara khusus para responden) untuk dapat melihat bagaimana manfaat pemahaman mereka tentang sejarah gereja lokal dalam perkembangan kepercayaan mereka sendiri.

Pertanyaan penelitian (rumusan masalah) yang muncul dalam artikel ini adalahBerapa besarkah indeks (persentase) manfaat pemahaman anggota jemaat warga jemaat kaum dewasa tentang sejarah gereja lokal dalam perkembangan kepercayaan di HKBP Resort Tampahan Balige Kabupaten Toba tahun 2019? Tujuan penelitian ini adalah untuk mengetahui indeks (persentase) manfaat pemahaman anggota jemaat kaum dewasa

${ }^{8}$ H. Sulasman, Metodologi Penelitian Sejarah, Teori, Metode, Contoh Aplikasi, ed. Beni Ahmad Saebani (Bandung: Pustaka Setia, 2014)., 21. 
tentang sejarah gereja lokal dalam perkembangan kepercayaan di HKBP Resort Tampahan di Kabupaten Toba tahun 2019.

\section{Metode Penelitian}

Penelitian ini menggunakan pendekatan kualitatif deskriptif, dilakukan dengan menggambarkan, membeberkan, atau menjelaskan variabel penelitian ${ }^{9}$, yang bertujuan untuk mengetahui indeks analisis manfaat pemahaman warga jemaat tentang sejarah gereja lokal dalam perkembangan kepercayaan anggota jemaat kaum dewasa di Gereja HKBP Tampahan Resort Tampahan Distrik XI Toba Hasundutan yang berada di Kelurahan Tampahan, Kabupaten Toba, Propinsi Sumatera Utara.Penelitian ini dilaksanakan selama kurang lebih enam bulan, yaitu mulai dari bulan Mei dan diselesaikan sampai dengan bulan Oktober 2019. Dalam pelaksanaanya, penelitian ini tidak menggunakan angka dalam mengumpulkan data-datanya. Namun demikian bukan berarti bahwa penelitian ini sama sekali tidak diperbolehkan menggunakan angka dalam deskripsi dan juga dalam melakukan analisis data-datanya. ${ }^{10}$

Data primer penelitian ini diperoleh dari jawaban pertanyaan wawancara terhadap 15 orang responden yang dipilih secara musyawarah mufakat oleh para majelis jemaat dengan dibantu oleh pendeta resort (jemaat induk). Dari sekian banyak calon responden yang ada, kelima belas orangtersebut sedikit banyak masih mengetahui dan mengingat sejarah gereja lokal dari tangan kedua (saksi hidup) masa itu, yaitu kakek-nenek kandung dan juga orangtua kandung mereka. Empat orang di antara mereka berusia antara 51 hingga 59 tahun. Selebihnya, yaitu 11 orang lagi, berusia antara 69 hingga 80 tahun. Data sekunder penelitian ini adalah semua data, dokumen dan informasi yang diperoleh dari para informan terutama para pelayan gereja yang dianggap paling mengetahui tentang sejarah gereja lokal HKBP Tampahan. Selain itu diperoleh dari hasil dokumentasi yang menunjang terhadap data yang berbentuk kata-kata tertulis maupun tindakan.

Fenomenologi dan pendekatan yang menjadi instrumen penelitian ini adalah angket wawancara sebagai sumber data sekunder dan juga dokumen-dokumen sejarah gereja tersebut yang isi dan keterbacaannya divalidasi.Penelitimelakukan pengklasifikasian (penggolongan atau pengkodean, coding, menurut kategori tertentu) atas jawaban pertanyaan wawancara lima belas orang responden yang dimulai dengan deskripsi data. Tujuannya adalah agar peneliti dapat dengan cepat dan mudah melakukan analisa data dan juga interpretasi data. Selanjutnya penelitimenarik kesimpulan yang mengarah kepada perolehan hasil penelitian.

Dukomen berupa tulisan (paper) Barita (Sejarah) Huria HKBP Tampahan Resort Tampahan Distrik XI Toba Hasundutan (1888-2013), yaitu dokumen kliping Jubileum (Ulang Tahun) 125 Tahun. Dokumen tersebut sekaligus menjadi alat (tool) bagi tim peneliti untuk melakukan triangulasi validitas instrumen pertanyaan wawancara dan juga validitas data hasil wawancara. ${ }^{11}$ Untuk menentukan indikator data variabel penelitian ini peneliti menggunakan check-list (daftar pemeriksaan) untuk dibubuhkan tanda centang (check, tally) pada kolom yang sesuai, ${ }^{12}$ persentase variabel yang dominan dari jawaban responden.

Analisis data dilakukan sejak awal pengumpulan data melalui pembacaan satu demi satu jawaban responden yang dikumpulkan secara tertulis dan terstruktur dan

9Suharsimi Arikunto, Prosedur Penelitian: Suatu Pendekatan Praktik (Jakarta: Rineka Cipta, 2010)., 9.

10Ibid., 10.

11Ibid., 16.

12Ibid., 206. 
mengklasifikasikannya untuk memecahkan masalah. ${ }^{13}$ Dalam analisa data, empat komponen yang merupakan proses siklus dan interaktif harus diperhatikan yaitu: pengumpulan data, deskripsi data, reduksi data, dan penyimpulan data.

Teknik analisa data non-eksperimen dalam penelitian ini dinyatakan dalam bentuk rata-rata nilai butir dan juga persentase, ${ }^{14}$ dengan terlebih dahulu melakukan pen-skor-an (scoring). Dari hasil analisis dan tampilan data tersebut, peneliti membuat dan menyusun interpretasi dalam bentuk narasi deskriptif yang menunjukkan kualitas gejala atau fenomena yang menjadi objek penelitian.

Berikut ini (Tabel 1) disajikan instrumen kisi-kisi pertanyaan wawancara berdasarkan indikator gabungan teori sejarawan gereja, Cornish dan Hutauruk:

Tabel 1

Kisi-kisi Pertanyaan Wawancara

Analisis Manfaat Pemahaman Warga Jemaat Tentang Sejarah Gereja Lokal di HKBP Tampahan Ressort Tampahan Distrik XI Toba Kabupaten Toba Tahun 2019

\begin{tabular}{|c|c|c|}
\hline No. & Indikator & Item Pertanyaan Wawancara \\
\hline \multirow{5}{*}{1} & \multirow{5}{*}{$\begin{array}{l}\text { Mengetahui dan memahami } \\
\text { persitiwa masa lalu }\end{array}$} & $\begin{array}{l}\text { 1. Apakah Anda pernah mendengar informasi dan memahami } \\
\text { tentang pelayanan misionaris: Tuan F. Kaiser, Tuan Spiecker, } \\
\text { Pdt. Friedrick Panggabean, Pdt. Jetro Hutauruk? }\end{array}$ \\
\hline & & $\begin{array}{l}\text { 2. Apakah Anda mendengar dan mengerti pelayanan keempat } \\
\text { misionaris tersebut dari : orangtua kandung, parhalado, } \\
\text { anggota jemaat, atau orang lain di luar anggota jemaat? }\end{array}$ \\
\hline & & $\begin{array}{l}\text { 3. Apakah Anda mendengar dan memahami pelayanan mereka } \\
\text { di bidang kerohanian (mis.: pelayanan gereja, bangunan fisik } \\
\text { gereja) dan di bidang non kerohanian (mis.: pertanian, } \\
\text { perkebunan, peternakan, pertukangan / bangunan)? }\end{array}$ \\
\hline & & $\begin{array}{l}\text { 4. Selain gereja dan sistem penatalayanannya sebagai } \\
\text { peninggalan bidang kerohanian, apakah masih ada } \\
\text { peninggalan pelayanan empat tokoh di atas pada bidang non } \\
\text { kerohanian? }\end{array}$ \\
\hline & & $\begin{array}{l}\text { 5. Apakah Anda mengerti bahwa para misionaris tersebut telah } \\
\text { berjuang agar segala bentuk usaha dan hasil pelayanan } \\
\text { mereka tetap berjalan dengan baik? }\end{array}$ \\
\hline \multirow{5}{*}{2} & \multirow{5}{*}{$\begin{array}{l}\text { Berjuang mempertahankan } \\
\text { pekerjaan yang baik }\end{array}$} & $\begin{array}{l}\text { 1. Apakah Anda masih menanam dan memelihara tanaman } \\
\text { (pohon buah, padi dan palawija) yang diwariskan keempat } \\
\text { misionaris tersebut? }\end{array}$ \\
\hline & & $\begin{array}{l}\text { 2. Apakah Anda masih mengikuti kegiatan kebaktian dan } \\
\text { pelayan rohani yang dirintis oleh para misionaris tersebut? }\end{array}$ \\
\hline & & $\begin{array}{l}\text { 3. Apakah Anda masih ikut memelihara irigasi yang } \\
\text { pembangunannya digagasi oleh para misionaris tersebut? }\end{array}$ \\
\hline & & $\begin{array}{l}\text { 4. Apakah Anda masih ikut memelihara gedung gereja yang } \\
\text { pembangunannya digagasi oleh para misionaris tersebut? }\end{array}$ \\
\hline & & $\begin{array}{l}\text { 5. Apakah Anda masih ikut memelihara gedung sekolah yang } \\
\text { pembangunannya digagasi oleh para misionaris tersebut? }\end{array}$ \\
\hline \multirow[b]{2}{*}{3} & \multirow{2}{*}{$\begin{array}{l}\text { Menciptakan yang lebih baik } \\
\text { lagi ke depan (orientasi untuk } \\
\text { masa depan) }\end{array}$} & $\begin{array}{l}\text { 1. Apakah anda ikut memberikan sumbangan uang untuk } \\
\text { mengembangkan gedung serbaguna untuk masa depan } \\
\text { gereja? }\end{array}$ \\
\hline & & $\begin{array}{l}\text { 2. Pada masa kini, apakah ada anggota jemaat yang menjadi } \\
\text { petani pengumpul (tokê) dari hasil tanaman (pohon buah, } \\
\text { padi dan palawija) yang diwariskan keempat misionaris } \\
\text { tersebut? }\end{array}$ \\
\hline
\end{tabular}

13Ibid., 16.

${ }^{14}$ Ibid., 12. 


\begin{tabular}{|c|c|c|}
\hline & \multirow{3}{*}{ 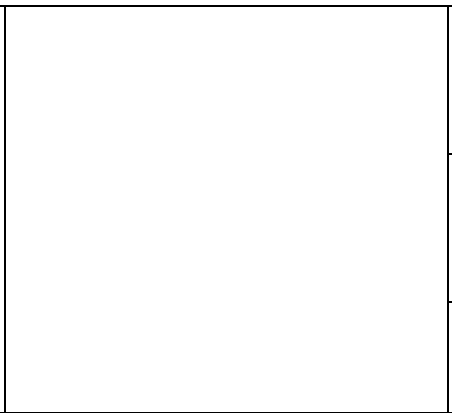 } & $\begin{array}{l}\text { 3. Dari hasil tanaman (pohon buah, padi dan palawija) unggul } \\
\text { yang diwariskan keempat misionaris tersebut, apakah ada } \\
\text { terbentuk kelompok tani di tengah-tengah jemaat pada masa } \\
\text { kini? }\end{array}$ \\
\hline & & $\begin{array}{l}\text { 4. Dari hasil tanaman (pohon buah, padi dan palawija) unggul } \\
\text { yang diwariskan keempat misionaris tersebut, apakah Anda } \\
\text { masuk menjadi anggota atau pengurus kelompok tani di } \\
\text { tengah-tengah jemaat? }\end{array}$ \\
\hline & & $\begin{array}{l}\text { 5. Apakah Anda masih ikut mengembangkan pembangunan } \\
\text { irigasi, gedung sekolah, gedung gereja yang } \\
\text { pembangunannya digagasi oleh misionaris tersebut? }\end{array}$ \\
\hline
\end{tabular}

\section{Hasil dan Pembahasan}

\section{Hasil Penelitian}

Deskripisi Data

Sebelas dari lima belas responden masih merasakan pengaruh pelayanan keempat misionaris tersebut. Oleh sebab responden yang tertua, lahir dua tahun setelah misionaris keempat (Pdt. Jetro Hutauruk, +1937) tutup usia. Dengan demikian kesebelas orang tersebut dianggap sebagai generasi ketiga jemaat gereja HKBP Tampahan, sejak misionaris I. L. Nommensen mengukuhkan Tuan F. Kaiser sebagai misionaris pertama di HKBP Tampahan. Informasi tentang sejarah gereja lokal dan penatalayanan keempat misionaris tersebut mereka peroleh dari kakek-nenek kandung dan orangtua kandung mereka masing-masing, sebagai pihak pertama. Kakek-nenek kandung mereka-lah melihat kinerja para misionaris tersebut, dan bukan hanya itu, mereka juga berada di dalam dinamika, interaksi dan mengalami langsung peristiwa penatalayanan para misionaris tersebut di dalam hidup keseharian mereka.

Pihak kedua yang memberikan informasi tersebut adalah para penatua yang satu generasi dengan kakek-nenek kandung dan orangtua kandung mereka masing-masing. Mereka menuturkan kisah sejarah gereja lokal dan penatalayanan keempat misionaris tersebut kepada mereka melalui khotbah dan percakapan informal saat mereka masih berusia anak-anak (Sekolah Minggu) hingga remaja atau muda-mudi (naposobulung). Kemudian, oleh sebab bukti fisik peninggalan hasil karya para misionaris tersebut masih terpelihara hingga saat ini di sekitar lokasi (pargodungan) gereja, maka para responden kelompok umur terakhir tersebut tidak sulit untuk memverifikasi informasi yang mereka terima, di samping masih banyak foto-foto para misionaris yang dapat dilihat di ruang konsistori dan rumah-rumah anggota jemaat HKBP Tampahan. Tentu saja keterangan yang mereka sampaikan tentang manfaat memahami sejarah gereja lokal tersebut sangat dibutuhkan oleh para generasi penerus gereja ini. Secara khusus, untuk pertama sekali, kakek-nenek mereka didatangi oleh manusia yang datang dari 'belahan dunia modern', yang membagikan 'teknologi' dan 'ketuhanan'-nya kepada manusia di negeri 'ketiga' masa itu.

Setelah melakukan pencatatan jawaban para responden dengan menggunakan pertanyaan wawancara terstruktur sebagaimana dipaparkan pada Tabel 1 yang lazim disebut dengan deskripsi data, kemudian dilakukan rekapitulasi dan reduksi data sekunder. Hasilnya ditunjukkan dalam Tabel 2. 
Tabel 2

Rekapitulasi Jawaban Responden Wawancara Tentang

Manfaat Pemahaman Warga Jemaat Sejarah Gereja Lokal

di HKBP Tampahan Resort Tampahan Distrik XI Kabupaten Toba Tahun 2019

\begin{tabular}{|c|c|c|c|c|c|c|c|c|c|c|c|c|c|c|c|}
\hline \multirow{2}{*}{$\begin{array}{c}\text { Nomor } \\
\text { Responden }\end{array}$} & \multicolumn{15}{|c|}{ Item Pertanyaan Wawancara } \\
\hline & 1 & 2 & 3 & 4 & 5 & 6 & 7 & 8 & 9 & 10 & 11 & 12 & 13 & 14 & 15 \\
\hline 1 & $\checkmark$ & $\checkmark$ & $\checkmark$ & $x$ & $x$ & $\checkmark$ & $\checkmark$ & $\checkmark$ & $\checkmark$ & $\checkmark$ & $\checkmark$ & $\checkmark$ & $\checkmark$ & $\checkmark$ & $\checkmark$ \\
\hline 2 & $\checkmark$ & $\checkmark$ & $\checkmark$ & $x$ & $x$ & $\checkmark$ & $\checkmark$ & $\checkmark$ & $x$ & $x$ & $\checkmark$ & $\checkmark$ & $\checkmark$ & $x$ & $\checkmark$ \\
\hline 3 & $\checkmark$ & $\checkmark$ & $\checkmark$ & $x$ & $x$ & $\checkmark$ & $\checkmark$ & $\checkmark$ & $x$ & $x$ & $\checkmark$ & $\checkmark$ & $\checkmark$ & $x$ & $\checkmark$ \\
\hline 4 & $\checkmark$ & $\checkmark$ & $\checkmark$ & $x$ & $x$ & $\checkmark$ & $\checkmark$ & $\checkmark$ & $x$ & $x$ & $\checkmark$ & $\checkmark$ & $\checkmark$ & $x$ & $\checkmark$ \\
\hline 5 & $\checkmark$ & $\checkmark$ & $\checkmark$ & $x$ & $x$ & $\checkmark$ & $\checkmark$ & $\checkmark$ & $\checkmark$ & $\checkmark$ & $\checkmark$ & $\checkmark$ & $\checkmark$ & $x$ & $\checkmark$ \\
\hline 6 & $\checkmark$ & $\checkmark$ & $\checkmark$ & $\checkmark$ & $\checkmark$ & $\checkmark$ & $\checkmark$ & $\checkmark$ & $\checkmark$ & $\checkmark$ & $\checkmark$ & $\checkmark$ & $\checkmark$ & $x$ & $\checkmark$ \\
\hline 7 & $\checkmark$ & $\checkmark$ & $\checkmark$ & $\checkmark$ & $\checkmark$ & $\checkmark$ & $\checkmark$ & $\checkmark$ & $\checkmark$ & $\checkmark$ & $\checkmark$ & $\checkmark$ & $\checkmark$ & $x$ & $\checkmark$ \\
\hline 8 & $\checkmark$ & $\checkmark$ & $\checkmark$ & $\checkmark$ & $\checkmark$ & $\checkmark$ & $\checkmark$ & $\checkmark$ & $\checkmark$ & $\checkmark$ & $\checkmark$ & $\checkmark$ & $\checkmark$ & $x$ & $\checkmark$ \\
\hline 9 & $\checkmark$ & $\checkmark$ & $\checkmark$ & $\checkmark$ & $\checkmark$ & $\checkmark$ & $\checkmark$ & $\checkmark$ & $\checkmark$ & $\checkmark$ & $\checkmark$ & $\checkmark$ & $\checkmark$ & $x$ & $\checkmark$ \\
\hline 10 & $\checkmark$ & $\checkmark$ & $\checkmark$ & $\checkmark$ & $\checkmark$ & $\checkmark$ & $\checkmark$ & $\checkmark$ & $\checkmark$ & $\checkmark$ & $\checkmark$ & $\checkmark$ & $\checkmark$ & $\checkmark$ & $\checkmark$ \\
\hline 11 & $\checkmark$ & $\checkmark$ & $\checkmark$ & $\checkmark$ & $\checkmark$ & $\checkmark$ & $\checkmark$ & $\checkmark$ & $\checkmark$ & $\checkmark$ & $\checkmark$ & $\checkmark$ & $\checkmark$ & $x$ & $\checkmark$ \\
\hline 12 & $\checkmark$ & $\checkmark$ & $x$ & $\checkmark$ & $\checkmark$ & $\checkmark$ & $\checkmark$ & $\checkmark$ & $\checkmark$ & $\checkmark$ & $\checkmark$ & $\checkmark$ & $\checkmark$ & $x$ & $\checkmark$ \\
\hline 13 & $\checkmark$ & $\checkmark$ & $\checkmark$ & $\checkmark$ & $\checkmark$ & $\checkmark$ & $\checkmark$ & $\checkmark$ & $\checkmark$ & $x$ & $\checkmark$ & $\checkmark$ & $\checkmark$ & $x$ & $\checkmark$ \\
\hline 14 & $\checkmark$ & $\checkmark$ & $\checkmark$ & $x$ & $x$ & $\checkmark$ & $\checkmark$ & $\checkmark$ & $x$ & $x$ & $\checkmark$ & $\checkmark$ & $\checkmark$ & $x$ & $\checkmark$ \\
\hline 15 & $\checkmark$ & $\checkmark$ & $\checkmark$ & $x$ & $x$ & $\checkmark$ & $\checkmark$ & $\checkmark$ & $x$ & $x$ & $\checkmark$ & $\checkmark$ & $\checkmark$ & $x$ & $\checkmark$ \\
\hline
\end{tabular}

Catatan:

$\checkmark=$ Ya, Setuju

$\mathbf{x}=$ Tidak, Tidak Setuju

Reduksi Data

Berdasarkan perolehan deskripsi data pada Tabel 2, berikut ini disajikan reduksi data jawaban setuju responden tentang manfaat pemahaman warga jemaat tentang sejarah gereja lokal di HKBP Tampahan Resort Tampahan Kabupaten Toba Tahun 2019. 
Tabel 3

Tabulasi Reduksi Jawaban Responden Tentang Manfaat Pemahaman Warga Jemaat Sejarah Gereja Lokal di HKBP Tampahan Resort Tampahan Distrik XI Kabupaten Toba Tahun 2019

\begin{tabular}{|c|c|c|c|c|c|c|c|c|c|c|c|c|c|c|c|c|}
\hline \multirow{2}{*}{ Responden } & \multicolumn{15}{|c|}{ Item Pertanyaan Wawancara } & \multirow{2}{*}{$\underset{\text { Item }}{\Sigma}$} \\
\hline & 1 & 2 & 3 & 4 & 5 & 6 & 7 & 8 & 9 & 10 & 11 & 12 & 13 & 14 & 15 & \\
\hline 1 & 1 & 1 & 1 & 0 & 0 & 1 & 1 & 1 & 1 & 1 & 1 & 1 & 1 & 1 & 1 & 13 \\
\hline 2 & 1 & 1 & 1 & 0 & 0 & 1 & 1 & 1 & 0 & 0 & 1 & 1 & 1 & 0 & 1 & 10 \\
\hline 3 & 1 & 1 & 1 & 0 & 0 & 1 & 1 & 1 & 0 & 0 & 1 & 1 & 1 & 0 & 1 & 10 \\
\hline 4 & 1 & 1 & 1 & 0 & 0 & 1 & 1 & 1 & 0 & 0 & 1 & 1 & 1 & 0 & 1 & 10 \\
\hline 5 & 1 & 1 & 1 & 0 & 0 & 1 & 1 & 1 & 1 & 1 & 1 & 1 & 1 & 0 & 1 & 12 \\
\hline 6 & 1 & 1 & 1 & 1 & 1 & 1 & 1 & 1 & 1 & 1 & 1 & 1 & 1 & 0 & 1 & 14 \\
\hline 7 & 1 & 1 & 1 & 1 & 1 & 1 & 1 & 1 & 1 & 1 & 1 & 1 & 1 & 0 & 1 & 14 \\
\hline 8 & 1 & 1 & 1 & 1 & 1 & 1 & 1 & 1 & 1 & 1 & 1 & 1 & 1 & 0 & 1 & 14 \\
\hline 9 & 1 & 1 & 1 & 1 & 1 & 1 & 1 & 1 & 1 & 1 & 1 & 1 & 1 & 0 & 1 & 14 \\
\hline 10 & 1 & 1 & 1 & 1 & 1 & 1 & 1 & 1 & 1 & 1 & 1 & 1 & 1 & 1 & 1 & 15 \\
\hline 11 & 1 & 1 & 1 & 1 & 1 & 1 & 1 & 1 & 1 & 1 & 1 & 1 & 1 & 0 & 1 & 14 \\
\hline 12 & 1 & 1 & 0 & 1 & 1 & 1 & 1 & 1 & 1 & 1 & 1 & 1 & 1 & 0 & 1 & 13 \\
\hline 13 & 1 & 1 & 1 & 1 & 1 & 1 & 1 & 1 & 1 & 0 & 1 & 1 & 1 & 0 & 1 & 13 \\
\hline 14 & 1 & 1 & 1 & 0 & 0 & 1 & 1 & 1 & 0 & 0 & 1 & 1 & 1 & 0 & 1 & 10 \\
\hline 15 & 1 & 1 & 1 & 0 & 0 & 1 & 1 & 1 & 0 & 0 & 1 & 1 & 1 & 0 & 1 & 10 \\
\hline$\Sigma$ Skor & 15 & 15 & 14 & 8 & 8 & 15 & 15 & 15 & 10 & 9 & 15 & 15 & 15 & 2 & 15 & 186 \\
\hline $\begin{array}{c}\text { Persentase } \\
(\%)\end{array}$ & 8,06 & 8,06 & 7,52 & 4,30 & 4,30 & 8.06 & 8.06 & 8.06 & 5,37 & 4,83 & 8,06 & 8,06 & 8,06 & 1,07 & 8,06 & 100 \\
\hline
\end{tabular}

\section{Pembahasan}

Tabel 4.4 dapat diketahui bahwa item pertanyaan nomor 1 dan 2 (indikator tentang mengetahui dan memahami peristiwa masa lalu), item pertanyaan nomor 6, 7 dan 8 (indikator berjuang mempertahankan pekerjaan yang baik), item pertanyaan nomor 11, 12, 13 dan 15 (indikator tentang menciptakan yang lebih baik lagi ke depan, orientasi untuk masa depan) menduduki rangking tertinggi dengan jumlah skor penuh 15. Ketiga indikator telah terwakili dengan jumlah minimal 2 item pertanyaan. Ini berarti bahwa pada tahun 2019, responden sudah menjalankan manfaat pemahaman mereka tentang sejarah gereja lokal di HKBP Tampahan Resort Tampahan Kabupaten Toba dengan indeks 72,54 \%. Bila diperhadapkan dengan teori interpretasi penelitian menurut Riduwan dan Akdon, ${ }^{15}$ maka angka tersebut berada pada interval kuat (level empat, 61\%-80\%). Bila ditelisik jawaban para responden dan kelompok umurnya, penulis menyimpulkan bahwa pertumbuhan kepercayaan mereka agaknya berada pada tahap kepercayaan eksistensial yang mengacu kepada universalitas, ${ }^{16}$ walaupun tahap tersebut belum seutuhnya dipenuhi.

Sedangkan yang menduduki renking paling rendah (yaitu pada indeks 1,07\%) adalah item pertanyaan nomor 14, dengan jumlah skor 2 (indikator tentang menciptakan yang lebih baik lagi/orientasi ke depan). Dalam hal ini, hanya ada dua orang responden yang masuk

${ }^{15}$ Riduwan, Buchari Alma, and Akdon, Rumus Dan Data Dalam Aplikasi Statistika $\square$ : Untuk Penelitian [Administrasi Pendidikan-Bisnis-Pemerintahan-Soial-Kebijakan-Ekonomi-Hukum-ManajemenKesehatan] (Bandung: Alfabeta, 2010)., 8.

${ }^{16}$ Agus Cremers and A. Supratiknya, Tahap-Tahap Perkembangan Kepercayaan Menurut James W. Fowler: Sebuah Gagasan Baru Dalam Psikologi Agama, ed. A Supratiknya (Yogyakarta: Kanisius, 1995)., 229-243. 
menjadi anggota atau pengurus kelompok tani di tengah-tengah jemaat sebagai hasil tanaman (pohon buah, padi dan palawija) unggul yang diwariskan misionaris terdahulu. Dalam hal ini bila dipandang dari usia mereka, masing-masing (responden 1 berusia 79 tahun dan responden 2 berusia 53 tahun), sesungguhnya kedua responden patut dihargai oleh sebab mereka masih mau dan bersedia menduduki jabatan penasihat dalam kelompok tani. Sementara 13 orang responden lainnya, oleh sebab faktor usia, mereka tidak sanggupuntuk menjadi anggota aktif kelompok tani. Ini juga berarti bahwa anggota kelompok tani masih memberikan penghormatan bagi para pendahulu mereka.

Apabila ditambah dengan kolom jumlah skor jawaban wawancara pada bagianbagian lainnya yang rata-rata di atas $50 \%$ (yaitu item pertanyaan nomor 4 dan 5, idikator tentang mengetahui dan memahami persitiwa masa lalu, dan juga 9 dan 10, indikator berjuang mempertahankan pekerjaan yang baik), maka responden penelitian yang sudah menjalankan manfaat pemahaman mereka tentang sejarah gereja lokal HKBP sesungguhnya berada pada indeks lebih besar dari 72,54\%, yaitu berada pada interval kuat (level empat, $61 \%-80 \%)$. Bila dilihat kasus per kasus, memang terdapat beberapa kejanggalan jawaban responden yang mengarah kepada situasi yang inkonsisten. Salah satu contohnya adalah responden nomor 12. Responden ini mendengar informasi dan memahami pelayanan keempat misionaris tersebut termasuk tantangan dan hambatan yang mereka hadapi saat itu hanya di bidang kerohanian saja, tidak ada di bidang non kerohanian (bnd. pelayanan holistik). Padahal responden ini ikut serta dalam dan memelihara tanaman (pohon buah, padi dan palawija) dan memelihara irigasi yang pengadaan dan pembangunannya digagasi oleh para misionaris. Situasi ini dapat dipahami, sebab responden ini menganggap bahwa semua yang dilakukan oleh para misionaris tersebut adalah berada dalam lingkup kerohanian sajatanpa ada pembedaan antara kerohanian dan nonkerohanian. Hal ini dapat dimungkinkan oleh sebab faktor mindset, latar belakang pendidikan dan juga faktor situasi responden yang sudah mencapai usia lanjut.

Terdapat juga kejanggalan jawaban responden 1-5, 14-15 tentang item pertanyaan wawancara nomor 4 (tidak menyadari bahwa masih ada warisan peninggalan para misionaris di bidang nonkerohanian) dan item pertanyaan wawancara nomor 5 (tidak mengetahui dan mengerti bahwa para misionaris tersebut telah berjuang agar segala bentuk usaha dan hasil pelayanan mereka tetap berjalan dengan baik). Padahal, sama seperti pada paragraf sebelumnya, responden ini sesungguhnya ikut serta danmasih menanam dan memelihara tanaman (pohon buah, padi dan palawija) dan memelihara irigasi yang pengadaan dan pembangunannya digagasi oleh para misionaris. Selain itu, tim peneliti telah memberikan penjelasan dan juga tayangan visual yang bersumber dari dokumen sejarah yang memperlihatkan tentang karya bakti para misionaris tersebut. Namun demikian terjadinya kejanggalan jawaban responden tersebut dapat dimungkinkan oleh sebab faktor usia, mindset dan juga latarbelakang pendidikan para responden tersebut.

Kejanggalan jawaban responden berikutnya adalah terdapat pada pertanyaan wawancara nomor 9 (ikut memelihara gedung gereja yang pembangunannya digagasi oleh para misionaris, yaitu responden nomor 2, 3, 4, 14 dan 15) dan pertanyaan wawancara nomor 10 (memelihara gedung sekolah yang pembangunannya digagasi oleh para misionaris, yaitu responden nomor 2, 3, 4, 13, 14 dan 15). Kejanggalan jawaban pertanyaan responden ini juga dipicu oleh pemahaman responden yang merasa bingung bahwa bangunan gedung Sekolah Dasar yang ada sekarang, tidak sama lagi dengan bangunan yang digagasi oleh para misionaris terdahulu, yang sudah tidak ada lagi oleh sebab sudah diganti (dirubuhkan) dengan bangunan sekolah yang didirikan pemerintah, walaupun lokasinya tepat berada di bangunan lama, yaitu bangunan sekolah yang pembangunannya digagasi oleh para misionaris. Tidak disadari pemerintah diberi izin hak guna lahan untuk mendirikan sekolah di atas lahan gereja. Dengan demikian perawatan gedung sekolah 
tentunya sudah dilakukan oleh pihak pemerintah dengan menunjuk petugas yang menjaga dan melakukan perawatan serta kebersihannya.

Untuk hal ini peneliti telah menerangkan bahwa lingkup pemeliharaan yang dimaksud adalah menjaga kebersihan (tidak membuang sampah dan puntung rokok sembarangan), bersedia memerintahkan atau menggerakkan anak-anak untuk menyapu, menutup pintu dan jendela sekolah dan gereja, bahwa mereka tidak harus terlibat secara langsung, namun wujud perhatian dan keperdulian mereka juga adalah bagian dari keikutsertan dalam melakukan tindakan perawatan. Tentunya semua hal tersebut juga telah mereka penuhi apabila mereka kebetulan sedang berada di lokasi gedung gereja dan sekolah tersebut ada saat hari Minggu (mengikuti kebaktian di gereja) atau hari biasa lainnya.

Item pertanyaan wawancara yang juga perlu dipahami adalah nomor 14, yaitu tentang responden (nomor 2-9 dan 11-15) yang tidak masuk menjadi anggota atau pengurus kelompok tani di tengah-tengah jemaat dari hasil tanaman (pohon buah, padi dan palawija) unggul yang diwariskan keempat misionaris. Untuk hal ini pun dapat dimungkinkan oleh sebab faktor usia, mindset dan juga latarbelakang pendidikan para responden tersebut. Hanya 2 dari 15 responden yang masuk menjadi pengurus kelompok tani, yaitu sebagai penasihat, sebagaimana telah diutarakan pada paragraf ketiga di atas.

Keterangan interpretasi di atas dapat diketahui bahwa sesungguhnya pada pelaksanaan penelitian tim peneliti tahun 2019 ini, para responden telah menarik manfaat dari pemahaman mereka akan sejarah gereja lokal (mereka sendiri) di HKBP yang berada pada indeks lebih besar dari 72,54\%. Lebih dari itu, selain sebagai penerima kesaksian warisan pelayanan para misionaris terdahulu, para responden berada di dalam barisan orang-orang yang [1] mengalami langsung manfaat pelayanan para misionaris gereja terdahulu dan juga [2] mengalami langsung manfaat dari pemahaman mereka akan sejarah gereja lokal demi mempersiapkan masa depan gereja yang lebih baik.

Walaupun para responden rata-rata telah berusia lanjut, namun mereka tetap memberikan perhatian dan ikut serta berpartisipasi dalam pemeliharaan saluran irigasi yang digagasi oleh misionaris Tuan F. Kaiser. ${ }^{17}$ Wujud perhatian dan keikutsertaan mereka dalam pemeliharaan irigasi tersebut adalah tetap menjaga agar pelaksanaan perawatan irigasi tersebut sesuai dengan petunjuk yang diberikan oleh yang misionaris Tuan F. Kaiser yaitu menjaga kebersihan dan kelancaran saluran irigasi, melakukan renovasi dan tindakan cepat perbaikan-perbaikan kecil, pengalihan sementara jalur air, sistem buka-tutup kran irigasi, konsistensi pelaksanaan jadwal, rapat anggota pengguna irigasi, sistem pemenuhan hak, tanggung jawab dan kewajiban anggota, dll.. Oleh sebab pelaksanaan sistem kerja dan perawatan irigasi tersebut sudah berbentuk tim operator perawatan, maka para responden dan juga warga jemaat (anggota) pengguna irigasi tersebut hanya membayarkan iuran wajib pemeliharaan yang ditetapkan melalui rapat anggota menurut kententuan yang baku setiap tahun.

Menutup bagian interpretasi dan pembahasan ini, penelitian ini juga menunjukkan hasil bahwa bahwa para responden mengalami sendiri manfaat dari pelayanan misionaris terdahulu hingga di zaman ini. Mereka juga mengalami sendiri manfaat pemahaman mereka tentang sejarah gereja lokal mereka sendiri. Mereka juga ingin dan masih mempertahankan dan menindaklanjutkan hal-hal yang telah digagasi oleh para misionaris tersebut oleh sebab penatalayanan yang mereka lakukan memberikan dampak langsung bagi mereka sendiri, tidak hanya perkembangan kepercayaan tetapi juga dalam lingkup ekonomi keluarga. Hal ini dibuktikan dengan tingginya indikator tentang menciptakan yang lebih baik lagi ke

17Pd. L. L. Tobing, Jubileum (1888-1938) Pesta Sere Ni HKBP Tampahan (26-12-1938) (Laguboti: Zendingsdrukkerij Laguboti, 1938)., 14. 
depan (orientasi untuk masa depan) dengan indeks 33,31\% bila dibandingkan dengan masing-masing dua indikator lainnya.

Penelitian ini juga telah memperlihatkan bahwa terdapat pengaruh langsung antara pelayanan para misionaris terdahulu dengan dengan tingkat kepercayaan para responden. Dari jawaban mereka yang dicatat oleh tim peneliti, sekalipun sedang menghadapi gejolak internal gereja, kesediaan mereka dalam mengikuti setiap kegiatan kegerejaan (kebaktian minggu, evangelisasi (partangiangan sektor), pesta-pesta dan perayaan-perayaan gerejawi) menunjukkan intensitas yang cukup tinggi. Indikasi ini juga dapat dilihat oleh tim peneliti dari antusias mereka menceritakan tindakan-tindakan yang telah mereka lakukan dalam memberikan usul dan solusi atas pergumulan jemaat. Kemudian, selain oleh sebab alasan sakit, mereka hampir tidak pernah absen dalam mengikuti kebaktian dan kegiatan kegerejaan (mengikuti kebaktian kegerejaan empat kali dalam satu bulan).

Aspek usia (setengah baya dan selanjutnya), dalam teori perkembangan kepercayaan menurut James Fowler, para responden berada pada tingkat kepercayaan konjungtif (tingkat 6) ${ }^{18}$ Namun bertitik tolak dari jawaban para responden dapat dilihat bahwa mereka agaknya berada pada level universalitas. Indikasi tahap ini dapat lihat pada diri responden, diantaranya: (1) Rela berkorban: para responden rela mengorbankan waktu, uang/harta, makanan, tenaga (pada masa muda), dalam mengikuti kegiatan-kegiatan penatalayanan gereja. Untuk saat ini para responden masih memberikan sumbangan materi dan perhatiannya dalam melanjutkan pembangunan (tahap finishing) gedung serbaguna milik gereja. (2) Mengatasi ikatan nilai dan kebendaan duniawi: selain poin satu di atas, seandainya anak (putra atau putri) mereka memiliki motivasi pelayanan yang sama kadarnya seperti para misionaris tersebut para responden mengaku bahwa mereka mengizinkan mereka meninggalkan keluarga dan kampung halamannya demi pelayanan kepada umat TUHAN. (3) Menciptakan pembebasan dan belenggu sosial: untuk melepaskan diri dari kemiskinan, kemalasan dan kebodohan, para responden rata-rata sudah pernah menjadi anggota aktif kelompok tani dan dua diatara mereka masih ada yang masih berstatus sebagai penasihat, mereka semakin rajin bekerja (di sawah, ladang, kantor, dan lainnya) dan semakin rajin dan rajin bekerja (yaitu dengan pengadaan bibit unggul, metode dan teknik kerja pertanian dan perkebunan), pun oleh pengaruh langsung dan kuat buah karya bakti penatalayanan para misionaris terdahulu. Selain itu hingga saat ini, para responden juga memberikan usul dan solusi atas pergumulan yang muncul di tengahtengah jemaat dan juga di sekitar buah penatalayanan gerejawi yang digagasi oleh para misionaris terdahulu.

Berdasarkan keterangan di atas, tim peneliti melihat adanya hubungan langsung hasil penelitian ini dengan tiga matakuliah yang saat ini ada di dalam kurikulum Program Studi Teologi (dan matakuliah lainnya pada kurikulum program studi lainnya), di antaranya: Strategi Pengembangan Gereja, Sejarah Gereja dan juga Strategi Perkembangan Kekeristenan. Materi sejarah gereja yang dipelajari di bagi dalam tiga bagian besar, yaitu: pertama, gereja kuno (30-590). Masa Gereja lahir dan berkembang dalam wilayah kekaisaran Roma sampai abad ke-6. Kedua, gereja abad pertengahan (590-1492/1517). Ketiga, gereja pada zaman baru (1492-1517-kini) ${ }^{19}$ Melalui jawaban para responden, jemaat HKBP Tampahan Ressort HKBP Tampahan Ressort Tampahan Kabupaten Toba nampak telah menikmati hasil karya bakti penatalayanan holistik yang sangat mempengaruhi

\footnotetext{
${ }^{18}$ Cremers and Supratiknya, Tahap-Tahap Perkembangan Kepercayaan Menurut James W. Fowler: Sebuah Gagasan Baru Dalam Psikologi Agama., 185-218.

${ }^{19}$ Leryani Mince Maria Manuain and Viktor Imanuel Nani, "Pemahaman Periodisasi Sejarah Gereja Umum Di Sekolah Tinggi Agama Kristen Negeri Kupang," Jurnal Ilmiah Religiosity Entity Humanity (JIREH) 1, no. 2 (December 2019): 187-193.
} 
kehidupan jemaat tidak hanya secara kerohanian, tetapi juga secara income ekonomi keluarga (non kerohanian).

Ini berarti bahwa model-model penatalayanan holistik sangat perlu diperkenalkan dan dimasukkan ke dalam matakuliah yang telah disebut pada paragraf sebelumnya. Secara khusus di era indutri generasi keempat saat ini sangat dibutuhkan penatalayanan gereja yang memuat unsur daya ekonomi kreatif, entrepreneurship (kewirausahaan), agro dan teknologi pertanian-peternakan. Sebab, melalui jawaban para responden, tim peneliti telah melihat bahwa pertumbuhan kepercayaan jemaat HKBP Tampahan Resort Tampahan Kabupaten Toba berhubungan langsung erat (bi-implikasi) dengan kehidupan keseharian dan juga kebutuhan hidup (ekonomi) anggota jemaat. Bahwa dengan pelayanan holistik, kegiatan gerejawi terasa lebih hidup dan bergerak, tidak hanya mengikuti kebaktian rutin, tetapi juga mengikat suasana kesatuan batin warga jemaat oleh sebab kegiatan mikroekonomi (income keuangan dan kebutuhan) warga jemaat sendiri juga ikut terikat di dalamnya. Aspek pelayanan holistik atau diakonia yang diberikan oleh gereja kepada jemaat secara tidak langsung telah memberikan transformasi atau perubahan bagi jemaat. Konsep ini sejalan dengan Herry Susanto yang menegaskan bahwa gereja di Indonesia harus mampu memaksimalkan pelayanan diakonia, bukan hanya sebagai kegiatan amal gereja, melainkan sebagai unsur penting pelayanan Kristen untuk menghadirkan transformasi bagi warga gereja dan masyarakat yang lebih luas. ${ }^{20}$ Dengan demikian, jasa-jasa para misionaris yang begitu besar atas penatalayaan holistik (kerohanian dan nonkerohanian) pada kehidupan para responden dan juga anggota jemaat HKBP Tampahan Resort Tampahan Kabupaten Toba sangat memberikan dampak yang besar.

\section{Kesimpulan}

Berdasarkan analisa klasifikasi data dan interpretasi organisasional yang dikembangkan dari kategori-kategori yang ditemukan dalam hubungan-hubungan sintesis dan hubungan-hubungan yang muncul dari data, yaitu dokumen Barita (Sejarah) Jubileum 125 Tahun Gereja HKBP Tampahan Ressort Tampahan Distrik XI Toba Hasundutan (18882013). Atas semua pertanyaan dan jawaban wawancara, dapat ditarik beberapa kesimpulan: pertama, jemaat kaum dewasa HKBP Tampahan Ressort Tampahan Kabupaten Toba telah menjalankan manfaat pemahaman mereka tentang sejarah gereja lokal dengan indeks $72,54 \%$, yaitu berada pada interval kuat atau tinggi. Kedua, sementara untuk indikator dengan indeks paling rendah, menciptakan yang lebih baik lagi/orientasi ke depan, yaitu $1,07 \%$. Hasil penelitian menunjukkan bahwa dua orang responden patut dihargai oleh sebab mereka masih mau dan bersedia menduduki jabatan penasihat dalam kelompok tani, walaupun mereka ada pada situasi lanjut usia.

Ketiga, secara umum kejanggalan-kejanggalan yang terjadi pada jawaban responden yang mengarah kepada situasi inkonsisten, dapat dipahami oleh peneliti. Dalam hal ini, sebelum melakukan tindakan wawancara, peneliti telah memberikan penjelasan tambahan yang memadai dan juga tayangan visual yang bersumber dari kliping dokumen sejarah yang memperlihatkan tentang karya bakti para misionaris tersebut. Peneliti dapat memahami dan menerima bahwa situasi tersebut dapat dimungkinkan oleh sebab faktor usia, mindset, dan juga latar belakang pendidikan para responden. Sangat mungkin mindset responden ini adalah bahwa misionaris hanyalah menekankan pada segi kerohanian-kepercayaannya saja pada awalnya. Keempat, sebagai penerima kesaksian (oleh situasi mereka sebagai generasi ketiga) warisan pelayanan para misionaris terdahulu, para responden berada di dalam

${ }^{20}$ Herry Susanto, "The Church as God's People and The Patner of State," Jurnal Jaffray 17, no. 1 (2019): 35-56. 
barisan orang-orang yang [1] mengalami langsung manfaat pelayanan para misionaris gereja terdahulu dan juga [2] mengalami langsung manfaat dari pemahaman mereka sendiri akan sejarah gereja lokal demi mempersiapkan masa depan gereja yang lebih baik. Dengan demikian para responden ini dapat dianggap telah ikut berjuang melestarikan warisan sejarah para pendahulu mereka.

Selain mengalami dan menerima manfaat kerohanian buah karya bakti para misioaris terdahulu, manfaat income ekonomi keluarga yang diperoleh para responden ternyata cukup kuat mendorong usaha penguatan untuk pemeliharaan dan pelestarian warisan sejarah. Itu berati pelayanan holistik kegerejaan tidak boleh lagi dipandang sebelah mata. Tetapi perlu diberi perhatian dan kajian tindak lanjut, secara khusus dalam pengembangan capaian yang sudah dialami dan dirasakan oleh warga jemaat HKBP Tampahan.

\section{Rujukan}

Arikunto, Suharsimi. Prosedur Penelitian: Suatu Pendekatan Praktik. Jakarta: Rineka Cipta, 2010.

Camerling, Yosua, and Hengki Wijaya. "Misi Dan Kebangkitan Rohani: Implikasi Misi Allah Bagi Gereja." Jurnal Ilmiah Religiosity Entity Humanity (JIREH) 1, no. 1 (2019): 57-71. https://ojs-jireh.org/index.php/jireh/article/view/11.

Cornish, Rick. 5 Menit Sejarah Gereja $\square$ : Kebenaran Maksimun Dalam Waktu Minimum. Bandung: Pionir Jaya, 2005.

Cremers, Agus, and A. Supratiknya. Tahap-Tahap Perkembangan Kepercayaan Menurut James W. Fowler $\square$ : Sebuah Gagasan Baru Dalam Psikologi Agama. Edited by A Supratiknya. Yogyakarta: Kanisius, 1995.

Gultom, Gomar, ed. Bunga Rampai Penghargaan Atas Pengabdian Pdt. Dr. J. R. Hutauruk, Menggapai Gereja Inklusif. Kantor Pusat HKBP Pearaja, 2004.

Manuain, Leryani Mince Maria, and Viktor Imanuel Nani. "Pemahaman Periodisasi Sejarah Gereja Umum Di Sekolah Tinggi Agama Kristen Negeri Kupang." Jurnal Ilmiah Religiosity Entity Humanity (JIREH) 1, no. 2 (December 23, 2019): 187-193.

Marpaung, Mangapul, and dkk., eds. Barita (Sejarah) Huria HKBP Tampahan Resort Tampahan Distrik XI Toba Hasundutan Taon 1888-2013. Balige, 2013.

Peneliti, Tim. "Wawancara Terhadap Pendeta HKBP Resort Tampahan (Pdt. Sarlen Lumbantobing, STh, MA.)," 2019.

Riduwan, Buchari Alma, and Akdon. Rumus Dan Data Dalam Aplikasi Statistika $\square$ : Untuk Penelitian [Administrasi Pendidikan-Bisnis-Pemerintahan-Soial-Kebijakan-Ekonomi-HukumManajemen-Kesehatan]. Bandung: Alfabeta, 2010.

Sinaga, Thomson M. P., and Bonar H. Nababan, eds. Bermisi Di Dalam Konteks, Transformasi Rekonsiliasi Pemberdayaan, Suatu Sumbangan Lutheran World Federation (LWF) Untuk Memahami Dan Melaksanakan Misi. Tarutung: Kantor Pusat Huria Kristen Batak Protestan [HKBP], 2008.

Siswanto, Krido. "Tinjauan Teoritis Dan Teologis Terhadap Diakonia Transformatif Gereja." Jurnal Simpson (n.d.): 95-120.

Sulasman, H. Metodologi Penelitian Sejarah, Teori, Metode, Contoh Aplikasi. Edited by Beni Ahmad Saebani. Bandung: Pustaka Setia, 2014.

Susanto, Herry. "Gereja Sebagai Umat Allah Dan Rekan Negara." Jurnal Jaffray 17, no. 1 (2019): 35-56. https://ojs.sttjaffray.ac.id/JJV71/article/view/298.

Tobing, Pd. L. L. Jubileum (1888-1938) Pesta Sere Ni HKBP Tampahan (26-12-1938). Laguboti: Zendingsdrukkerij Laguboti, 1938. 